\title{
ANALISIS PERILAKU SISWA/I SMA/SEDERAJAT DI WILAYAH TENGAH KABUPATEN BOGOR DALAM PENGAMBILAN KEPUTUSAN PEMILIHAN PERGURUAN TINGGI
}

\section{ANALYSIS OF HIGH SCHOOL STUDENT BEHAVIOR IN THE MIDDLE REGION OF BOGOR DISTRICT IN THE HIGHER EDUCATION SELECTION DECISION MAKING}

\author{
A Yoesdiarti1a \\ 1 Program Studi Agribisnis, Fakultas Pertanian, Universitas Djuanda Bogor, Jl. Tol Ciawi No. 1 \\ Kotak Pos 35 Ciawi Bogor 16720 \\ a Korespondensi: Arti Yoesdiarti, Email: arti.yoesdiarti@unida.ac.id \\ (Diterima: 30-01-2018; Ditelaah: 30-01-2018; Disetujui: 10-04-2018)
}

\begin{abstract}
Competition in higher education industry is getting tight. Understanding consumer behavior of potential market share will be very valuable for colleges to conduct effective and efficient marketing. This study aimed to identify students' profiles of equivalent SMAs, identify decision-making processes in choosing majors and colleges, analyze attributes that are considered important in choosing colleges, and analyze most interesting colleges for high school students in the Central Area, Bogor District. The study was conducted in September October 2017 at six high schools that were choosen purposively with the number of respondents 302 people. Data is processed descriptively. Assessment for criterias to choose college using Likert scale. The results show that the majority of respondent's parents earn $\leq$ Rp. 5.000.000. They were mostly majors at science. Interest in respondents to continue education to college was high enough. Almost all respondents thought that continuing to college was important. Decision-making to choose a college was dominated by respondents. Parents become decision makers in second place. Selected colleges were majority state college. Private colleges were only selected by $15.61 \%$ of respondents. Four faculties / study programs with the most consecutive enthusiasts are medical, education, sharia / religious science and engineering. Overall, respondents preferred social based majors compared to science. $39.50 \%$ Respondents admitted that they were still hesitant in choosing the major, while $36.74 \%$ have felt confident about the decision, and $23,76 \%$ were feeling not sure about their decision. Of the 10 promotional media, average media accessed were between 3 to 4 media. The most frequently accessed media in a row are: social media, websites, information from teachers. The three highest criteria in choosing a college are the availability of majors that they were interest in, the quality of the college, then the building and the complete facilities. Top three selected universities are University of Indonesia (23.77\%), IPB (16.59\%), and UGM (12.56\%).
\end{abstract}

Key words: college, student behavior.

\section{ABSTRAK}

Persaingan di dunia akademi, terutama perguruan tinggi, semakin ketat. Pemahaman akan perilaku konsumen pangsa pasar potensial akan sangat berharga bagi perguruan tinggi untuk melakukan pemasaran yang efektif dan efisien. Penelitian ini bertujuan untuk mengidentifikasi profil siswa/i SMA sederajat, mengidentifikasi proses pengambilan keputusan dalam memilih jurusan dan perguruan tinggi, menganalisis atribut yang dianggap penting dalam memilih perguruan tinggi, dan menganalisis perguruan tinggi yang diminati 
oleh siswa/i SMA/sederajat di Wilayah Tengah Kabupaten Bogor. Penelitian dilakukan bulan September - Oktober 2017 dengan mengambil lokasi di 4 SMA negeri, 1 SMA swasta, 1 MA Negeri dan 1 MA swasta secara purposif dengan jumlah responden 302 orang. Data diolah secara deskriptif. Penilaian kepentingan kriteria pemilihan perguruan tinggi menggunakan skala Likert. Hasil menunjukkan bahwa orang tua responden mayoritas berpenghasilan $\leq \mathrm{Rp}$ 5.000.000. Asal jurusan di sekolah mayoritas dari IPA. Minat responden cukup tinggi untuk melanjutkan pendidikan ke perguruan tinggi. Hampir seluruh responden menilai bahwa melanjutkan ke perguruan tinggi adalah hal penting. Pengambilan keputusan untuk memilih perguruan tinggi didominasi oleh diri sendiri. Orang tua menjadi pengambil keputusan di peringkat kedua. Perguruan tinggi yang dipilih mayoritas berstatus negeri. Perguruan tinggi swasta hanya dipilih oleh 15,61\% responden. Empat fakultas/program studi dengan peminat terbanyak berturut-turut adalah kedokteran, pendidikan, syariah/ilmu agama dan teknik. Secara keseluruhan, responden lebih banyak memilih jurusan berbasis IPS dibandingkan IPA. 39,50\% Responden mengaku masih ragu dalam memilih jurusan, sementara 36,74\% sudah merasa yakin akan keputusannya, dan 23,76\% tidak yakin. Dari 10 media promosi, rata-rata responden mengakses 3 sampai 4 media. Media paling banyak diakses berturut turut adalah : media sosial, website, informasi dari guru. Tiga kriteria tertinggi dalam mmilih perguruan tinggi adalah tersedianya jurusan yang diminati, kualitas perguruan tinggi, lalu gedung dan sarana yang lengkap. Perguruan tinggi yang banyak dipilih adalah Universitas Indonesia (23,77\%), IPB (16,59\%), dan UGM (12,56\%).

Kata kunci: perilaku siswa, perguruan tinggi.

Yoesdiarti, A. 2018. Analisis Perilaku Siswa/i SMA/Sederajat di Wilayah Tengah Kabupaten Bogor dalam Pengambilan Keputusan Pemilihan Perguruan Tinggi. Jurnal Sosial Humaniora 9(1): 70-79.

\section{PENDAHULUAN}

Pendidikan adalah hal yang sangat penting dalam upaya untuk meningkatkan kualitas sumberdaya manusia. Sumberdaya manusia yang berkualitas akan meningkatkan daya saing, terutama di era global dimana sumberdaya manusia dari negara lain dapat dengan mudah bekerja di Indonesia. Peningkatan kebutuhan pendidikan menyebabkan meningkatnya jumlah perguruan tinggi baik di Indonesia maupun di Jawa Barat. Di Indonesia tercatat terdapat 4.598 perguruan tinggi yang terdiri dari 410 negeri dan 4.197 swasta, sementara di Jawa Barat tercatat 36 perguruan tinggi negeri dan 529 perguruan tinggi swasta.

Pemahaman terhadap perilaku siswasiswi SMA dalam mengambil keputusan untuk memilih perguruan tinggi akan menjadi informasi yang berharga bagi manajemen di perguruan tinggi, sehingga dapat menerapkan strategi terbaik untuk menyerap siswa-siswi SMA untuk melanjutkan pendidikan di perguruan tinggi di tempat mereka. Berdasarkan data dari Kemendikbud (2017), di Kabupaten Bogor, pada tahun 2016-2017 terdapat siswa SMA sejumlah 29.466 orang dan siswa SMK sejumlah 29.466. Sementara jumlah siswa di Madrasah Aliyah sekitar 15.000 orang (data tahun 2013-2014).

Pada tahun 2016, Angka Partisipasi Sekolah pada kelompok usia 19 - 24 tahun adalah 24,77\%. 16-18 adalah 71,42\%. Jika $25 \%$ berminat untuk melanjutkan kuliah, maka ada sejumlah 5.689 orang siswa/i yang dapat menjadi pasar potensial bagi perguruan tinggi. Jika APS di Bogor lebih tinggi dari 25\%, maka jelas angka tersebut akan meningkat. Namun kecenderungan siswa/i untuk memilih perguruan tinggi negeri sangatlah tinggi, padahal jumlah perguruan tinggi negeri yang ada jauh di bawah perguruan tinggi swasta. 
Berdasarkan permasalahan di atas, maka penelitian ini ditujukan untuk:

1. mengidentifikasi profil siswa/i di wilayah Tengah Kabupaten Bogor sebagai masukan dalam melakukan segmentasi pasar;

2. mengidentifikasi langkah-langkah pengambilan keputusan pemilihan program studi maupun pemilihan perguruan tinggi oleh siswa/i SMA/sederajat di Wilayah Tengah Kabupaten Bogor;

3. menganalisis atribut apa saja yang dipertimbangkan oleh siswa/i SMA/sederajat di Wilayah Tengah Kabupaten Bogor dalam memilih perguruan tinggi;

4. menganalisis pilihan utama perguruan tinggi yang diminati oleh siswa/i SMA/sederajat di Wilayah Tengah Kabupaten Bogor.

Diharapkan hasil penelitian ini dapat menjadi masukan bagi perguruan tinggi yang ingin meraih pangsa pasar yang berasal dari Kabupaten Bogor.

\section{MATERI DAN METODE}

Penelitian dilakukan pada bulan September - Oktober 2017 dengan mengambil lokasi di 4 SMA negeri, 1 SMA swasta, 1 Madrasah Aliyah Negeri dan 1 Pondok Pesantren (AsSalam). Pemilihan sekolah dilakukan secara purposif yaitu berdasarkan jumlah siswa yang relatif besar di Kab. Bogor Wilayah Tengah dan memang bersedia untuk dikunjungi oleh peneliti. Setiap sekolah dipilih 1 kelas (kelas XI) sesuai ketersediaan waktu luang yang disediakan pihak sekolah. Data primer diambil melalui kuisoner yang disebarkan ke siswa-siswi. Responden yang mengisi kuisioner adalah sebanyak 382 orang, namun yang digunakan datanya sebanyak 302 orang. Data diolah dengan menggunakan analisis deskriptif. Penilaian kepentingan atribut perguruan tinggi menggunakan skala Likert 1 sampai dengan
10. Alat yang digunakan dalam pengolahan data adalah Microsoft Excel. Atribut yang dinilai ada 14 atribut yang mewakili atribut jasa (7P), yaitu: Product (tersedia jurusan yang dipilih, kualitas perguruan tinggi, iklim pergaulan yang nyaman), Price (biaya terjangkau, kemudahan beasiswa), place (lokasi dekat rumah, lokasi strategis), promotion (keluarga/kenalan banyak yang memberi rekomendasi, ketenaran kampus), people (banyaknya mahasiswa yang kuliah di kampus tersebut), physical evidence (gedung dan sarana yang lengkap, banyak alumni sukses), process (kemudahan untuk lulus, waktu kuliah yang singkat dan fleksibel).

\section{HASIL DAN PEMBAHASAN}

\section{Profil Responden}

Jumlah responden yang memenuhi syarat adalah sebanyak 302 orang. Sebaran responden berdasarkan sekolah tertera pada tabel 1. Jumlah responden pada setiap sekolah relatif sama karena pengambilan sampel dilakukan di 1 kelas.

Tabel 1 Jumlah responden berdasarkan sekolah

\begin{tabular}{lrr}
\hline \multicolumn{1}{c}{ Sekolah } & Jumlah & $\%$ \\
\hline MAN 4 & 40 & $13,25 \%$ \\
SMAN 1 Cigombong & 43 & $14,24 \%$ \\
SMAN 1 Caringin & 42 & $13,91 \%$ \\
Ponpes Assalam & 50 & $16,56 \%$ \\
SMAN 1 Ciawi & 42 & $13,91 \%$ \\
SMAN 1 Megamendung & 42 & $13,91 \%$ \\
SMA Cisarua & 43 & $14,24 \%$ \\
Jumlah & 302 & $100 \%$ \\
\hline
\end{tabular}

Mayoritas responden berjenis kelamin laki-laki (54,52\%). Pada sekolah umum, responden mayoritas adalah perempuan, namun untuk Ponpes As Salam seluruh respondennya adalah laki-laki. Proporsi responden berdasarkan jenis kelamin tertera pada tabel 2 . 
Tabel 2 Sebaran responden berdasarkan jenis kelamin

\begin{tabular}{lrr}
\hline Jenis Kelamin & Jumlah & \multicolumn{1}{c}{$\%$} \\
\hline Perempuan & 137 & $45,48 \%$ \\
Laki-laki & 165 & $54,52 \%$ \\
Jumlah & 302 & $100 \%$ \\
\hline
\end{tabular}

Pada tabel 3, dapat dilihat bahwa penghasilan orang tua responden bervariasi, namun mayoritas responden (54,43\%) menjawab bahwa penghasilan mereka berada di bawah Rp 3.000.000. Penghasilan ini berada diantara UMR Kabupaten Bogor sehingga dapat menjadi kendala bagi responden untuk melanjutkan pendidikan ke perguruan tinggi. Responden dengan penghasilan orang tua 3.000.001 5.000 .000 berjumlah 30,16\%. Jika dikelompokkan, orang tua responden sebanyak 84,59\% berpenghasilan sama dengan atau di bawah Rp 5.000.000.

Tabel 3 Sebaran responden berdasarkan penghasilan orang tua

\begin{tabular}{lrr}
\hline \multicolumn{1}{c}{ Penghasilan } & Jumlah & \multicolumn{1}{c}{$\%$} \\
\hline$<3.000 .000$ & 164 & $54,43 \%$ \\
$3.000 .001-5.000 .000$ & 91 & $30,16 \%$ \\
$5.000 .001-7.500 .000$ & 31 & $10,16 \%$ \\
$7.500 .001-10.000 .000$ & 9 & $2,95 \%$ \\
$>10.000 .000$ & 7 & $2,30 \%$ \\
Jumlah & 302 & $100 \%$ \\
\hline
\end{tabular}

Asal jurusan di sekolah mayoritas IPA, yaitu sebanyak $88,74 \%$. Karena pemilihan kelas yang dapat dijadikan responden memang ditentukan oleh pihak sekolah, maka kondisi ini tidak dapat diatur oleh peneliti. Namun di sekolah-sekolah yang dipilih sebagai sasaran responden, jurusan IPA memang lebih dominan daripada IPS.

Tabel 4 Jurusan di sekolah

\begin{tabular}{crr}
\hline Jurusan & Jumlah & \multicolumn{1}{l}{$\%$} \\
\hline IPA & 268 & $88,74 \%$ \\
IPS & 34 & $11,26 \%$ \\
Jumlah & 302 & $100 \%$ \\
\hline
\end{tabular}

Setelah lulus SMA/sederajat, mayoritas responden (68,01\%) menjawab akan melanjutkan pendidikan ke perguruan tinggi. Sejumlah 5,91\% responden berminat untuk kuliah sambil bekerja. Sehingga diperkirakan $72,92 \%$ responden akan melanjutkan pendidikan ke perguruan tinggi. Sementara, 15,86\% memilih untuk bekerja, dan 10,22\% memilih untuk berbisnis sendiri (berwirausaha). Total responden yang memilih untuk tidak melanjutkan pendidikan adalah sebesar $26,08 \%$. Respon positif ini dapat disikapi oleh pihak perguruan tinggi maupun pemerintah agar dapat mengakomodir keinginan para siswa/i SMA/sederajat. Terkait dengan kendala biaya yang tersirat dari penghasilan orang tua, pemerintah maupun perguruan tinggi dapat meningkatkan program beasiswa yang berasal dari pemerintah, yayasan yang bergerak dalam pendanaan pendidikan maupun perusahaan swasta yang memiliki kepedulian terhadap pendidikan seusai dengan kewajiban Corporate Social Responsibility (CSR).

Tabel 5 Rencana setelah lulus SMA

\begin{tabular}{lrr}
\hline Rencana setelah Lulus & Jumlah & \multicolumn{1}{c}{$\%$} \\
\hline Bekerja & 48 & $15,86 \%$ \\
Kuliah & 205 & $68,01 \%$ \\
bekerja sambil kuliah & 18 & $5,91 \%$ \\
Bisnis sendiri & 31 & $10,22 \%$ \\
Jumlah & 302 & $100 \%$ \\
\hline
\end{tabular}

\section{Minat Responden}

Hampir seluruh responden menilai bahwa melanjutkan pendidikan ke perguruan tinggi adalah hal yang penting, yaitu sejumlah 98,22\%. Hal ini menunjukkan bahwa kesadaran para responden terhadap pendidikan tinggi sebenarnya sangat baik. Alasan terbanyak dari pentingnya melanjutkan pendidikan ke jenjang yang lebih tinggi adalah untuk mendapatkan ilmu yang lebih baik $(51,2 \%)$ dan untuk mewujudkan meraih cita-cita $(33,21 \%)$. Sisanya jawaban beragam, yaitu untuk memperoleh lebih banyak teman dan relasi $(10,25 \%)$ dan untuk memperoleh penghargaan dari lingkungan, serta lainlain. 
Walaupun menganggap penting, namun sesuai jawaban di tabel 5, masih ada $26,08 \%$ responden yang tidak berminat melanjutkan pendidikan. Ketika ditanyakan lebih lanjut alasan mengapa sejumlah 26,08\% responden tidak berminat melanjutkan kuliah, mayoritas menjawab karena tidak ingin membebani orang tua. Ketika ditanyakan lebih jauh, ternyata masih ada orang tua yang masih menganggap bahwa melanjutkan ke perguruan tinggi itu tidak penting, karena dengan menjadi buruh atau pegawai lepas di tempat wisata, penghasilan mereka bisa jadi lebih baik dari yang berpendidikan Diploma atau Sarjana.

Tabel 6 Kepentingan melanjutkan pendidikan ke perguruan tinggi

\begin{tabular}{lrr}
\hline \multicolumn{1}{c}{ Kepentingan } & Jumlah & \multicolumn{1}{c}{$\%$} \\
\hline Penting & 297 & $98,22 \%$ \\
Tidak Penting & 5 & $1,78 \%$ \\
Jumlah & 302 & $100 \%$ \\
\hline
\end{tabular}

Selanjutnya data diambil dari 223 responden yang memilih untuk melanjutkan pendidikan ke perguruan tinggi baik sambil bekerja maupun tidak. Pengambilan keputusan dalam memilih perguruan tinggi didominasi oleh diri sendiri (59,19\%). Responden menyatakan bahwa kuliah harus sesuai dengan kebutuhan dan pertimbangan mereka (Pertimbangan responden akan dibahas selanjutnya). Walaupun demikian, masukan pihak keluarga tetap dipertimbangkan karena harus menyesuaikan dengan kemampuan orang tua dalam membiayai perkuliahan. Orang tua, jika digabungkan, menjadi pengambil keputusan bagi 29,15\% responden. Orang tua dianggap lebih mengetahui keputusan terbaik karena selain kualitas dan prospek kerja, orang tua juga mempertimbangkan faktor akses ke perguruan tinggi (mudah dijangkau), lingkungan yang nyaman dan mendukung, dan biaya. Sisanya diputuskan oleh pihak yang membiayai selain orang tua/saudara kandung $(7,62 \%)$ dan kakak (9\%). Persentase pengambilan keputusan dalam memilih perguruan tinggi dapat diihat pada Tabel 7.
Tabel 7 Pengambilan keputusan dalam memilih perguruan tinggi

\begin{tabular}{lcc}
\hline \multicolumn{1}{c}{ Pengambil keputusan } & Jumlah & $\%$ \\
\hline Ayah & 34 & $15,25 \%$ \\
Ibu & 31 & $13,90 \%$ \\
Kakak & 9 & $4,04 \%$ \\
Diri sendiri & 132 & $59,19 \%$ \\
Pihak yang membiayai & 17 & $7,62 \%$ \\
Jumlah & 223 & $100 \%$ \\
\hline
\end{tabular}

Adapun perguruan tinggi yang dipilih pertama kali oleh responden mayoritas berstatus perguruan tinggi negeri, yaitu 84,39\%. Perguruan tinggi swasta hanya dipilih oleh 15,61\% responden. Sebagaimana tertera pada tabel 8. Adapun untuk pilihan kedua, presentasi yang memilih perguruan tinggi berkurang menjadi $80 \%$, dan $20 \%$ lainnya memilih perguruan tinggi swasta. Ketika ditanya lebih lanjut pada beberapa resonden, alasan memiih perguruan tinggi negeri adalah karena kualitasnya lebih bagus oleh responden. Persepsi bahwa perguruan tinggi negeri lebih berkualitas dan bergengsi memang sudah menjadi mindset mayoritas penduduk Indonesia. Ketika ditanyakan pemahaman mengenai akreditasi, mayoritas sudah mengetahui akreditasi sebagai patokan kualitas program studi maupun perguruan tinggi, namun hanya sedikit diantara responden yang mengetahui bahwa program studi di perguruan tinggi swasta sudah banyak yang memperoleh akreditasi unggul atau baik.

Tabel 8 Status perguruan tinggi pilihan pertama

\begin{tabular}{crcrc}
\hline \multirow{2}{*}{ Status } & \multicolumn{2}{c}{ Pilihan Pertama } & \multicolumn{2}{c}{ Pilihan Kedua } \\
\cline { 2 - 5 } & Jumlah & \multicolumn{1}{c}{$\%$} & Jumlah & $\%$ \\
\hline Negeri & 188 & $84,39 \%$ & 178 & $80 \%$ \\
Swasta & 35 & $15,61 \%$ & 45 & $20 \%$ \\
Jumlah & 223 & $100 \%$ & 223 & $100 \%$ \\
\hline
\end{tabular}

Fakultas/program studi yang dipilih oleh mayoritas responden adalah kedokteran $(16,89 \%)$, pendidikan $(13,2 \%)$, syariah atau 
ilmu agama $(9,9 \%)$ dan teknik $(8,94 \%)$. Walaupun banyak yang memilih kedokteran, namun secara keseluruhan responden lebih banyak yang memilih jurusan berbasis sosial (IPS), yaitu sejumlah $60 \%$. Hal ini memang kurang sesuai dengan jurusan asal responden di SMA/sederajat. Di sekolahnya, mayoritas responden $(88,74 \%)$ berasal dari jurusan sosial. Ketika ditanyakan lebih lanjut mengenai hal ini, responden menjawab memilih program studi IPA saat di SMA karena terkesan lebih bermutu dan orang tua lebih menyukai anaknya masuk jurusan IPA.

Tabel 9 Fakultas/jurusan yang dipilih oleh responden

\begin{tabular}{|c|c|c|c|}
\hline \multicolumn{2}{|l|}{ BERBASIS IPA } & \multicolumn{2}{|c|}{ BERBASIS IPS } \\
\hline Jurusan & $\%$ & Jurusan & Jumlah \\
\hline Kedokteran & $16,89 \%$ & Pendidikan & $13,20 \%$ \\
\hline Teknik (mesin, pertambangan) & $8,94 \%$ & Syariah/ keagamaan & $9,90 \%$ \\
\hline Sains & $3,64 \%$ & Sastra & $7,90 \%$ \\
\hline Pertanian & $2,98 \%$ & Akuntansi & $4,60 \%$ \\
\hline Teknologi Informasi & $2,98 \%$ & Psikologi & $4,00 \%$ \\
\hline Lainnya & $4,58 \%$ & Seni & $3,60 \%$ \\
\hline & & Komunikasi & $3,30 \%$ \\
\hline & & Hukum & $3,00 \%$ \\
\hline & & Manajemen & $2,30 \%$ \\
\hline & & Lainnya & $8,00 \%$ \\
\hline Jumlah & $40,00 \%$ & Jumlah & $60,00 \%$ \\
\hline
\end{tabular}

Saat memilih jurusan, $43,5 \%$ responden menjawab bahwa jurusan yang mereka pilih telah sesuai dengan minat, dan 27,35\% responden menjawab sesuai dengan minat. Jika digabungkan maka $70,85 \%$ responden memilih jurusan yang sesuai dengan minat mereka. Sementara 18,55\% netral/ragu dan sisanya kurang sesuai/tidak sesuai.

Tabel 10 Kesesuaian jurusan dengan minat

\begin{tabular}{lcr}
\hline \multicolumn{1}{c}{ Kesesuaian } & Jumlah & \multicolumn{1}{c}{$\%$} \\
\hline Sangat tidak sesuai & 15 & $6,73 \%$ \\
Tidak sesuai & 8 & $3,59 \%$ \\
Netral & 41 & $18,39 \%$ \\
Sesuai & 61 & $27,35 \%$ \\
Sangat sesuai & 97 & $43,50 \%$ \\
Jumlah & 223 & $100,00 \%$ \\
\hline
\end{tabular}

Responden yang menyatakan berminat melanjutkan ke perguruan tinggi (sejumlah 223 orang) ternyata mayoritas mengaku masih ragu dalam memilih jurusan saat kuliah nanti $(39,50 \%)$. Sementara $36,74 \%$ sudah merasa yakin akan keputusannya, dan $23,76 \%$ tidak memiliki keyakinan pasti akan jurusan yang akan dipilih saat kuliah. Hal ini tertera pada Tabel 11. Beberapa responden yang masih ragu akan jurusannya tidak begitu memahami cita-cita, minat serta bakatnya. Ketika ditanyakan cita-cita mau jadi apa, beberapa responden tersebut masih menunjukkan ketidakyakinan akan jawaban yang disampaikan. Bahkan masih banyak diantara responden yang tidak mengetahui jurusan apa saja yang ada di perguruan tinggi dan jenis pekerjaan apa saja yang dapat dipilih. Kondisi ini dapat dipergunakan oleh perguruan tinggi untuk terjun langsung ke sekolah-sekolah mengenalkan program studi maupun prospek pekerjaan yang dapat ditekuni. Selain promosi, kunjungan ke sekolah juga bermakna bagi siswa/i jika diberi informasi yang mereka butuhkan untuk masa depan mereka.

Tabel 11 Keyakinan memilih jurusan

\begin{tabular}{lrr}
\hline \multicolumn{1}{c}{ Keyakinan } & \multicolumn{1}{c}{ Jumlah } & \multicolumn{1}{c}{$\%$} \\
\hline Yakin & 82 & $36,74 \%$ \\
Masih ragu & 88 & $39,50 \%$ \\
Tidak tahu & 53 & $23,76 \%$ \\
Jumlah & 223 & $100,00 \%$ \\
\hline
\end{tabular}


Tabel 12 menunjukkan bahwa sebanyak $58,94 \%$ responden belum pernah mengikuti tes psikologi atau tes terkait minat dan bakat. Jawaban ini melatarbelakangi keyakinan responden saat memilih jurusan ketika masih banyak yang ragu atau tidak tahu jurusan yang akan dipilih. Saat ditanyakan di depan kelas akan pemahaman mengenai kelebihan dan kekurangan diri, responden terlihat masih banyak yang belum memahami karakter dan kemampuan diri. Hanya sekitar $10-20 \%$ saja dari responden yang berani mengangkat tangan dan menyampaikan mengenai karakter dan kemampuan dirinya.

Tabel 12 Keikutsertaan tes psikologi atau tes minat dan bakat

\begin{tabular}{lcr}
\hline \multicolumn{1}{r}{ Tes } & Jumlah & \multicolumn{1}{r}{$\%$} \\
\hline Ya & 124 & $41,06 \%$ \\
Tidak & 178 & $58,94 \%$ \\
Jumlah & 302 & $100 \%$ \\
\hline
\end{tabular}

Pencarian informasi mengenai perguruan tinggi dilakukan melalui berbagai media. Dari 10 media yang memungkinkan untuk diakses, rata-rata responden mengakses 3,7 media atau dibulatkan 4 media. Mayoritas responden $(20,63 \%)$ membutuhkan untuk mencari informasi setidaknya ke 3 media. Responden yang menjawab membutuhkan untuk mengakses ke 4 media sejumlah 17,49\%. Lainnya memberi jawaban yang beragam. Hal ini menunjukkan bahwa program promosi tidak dapat dilakukan hanya menggunakan $1-2$ media saja. Promosi harus dilakukan dengan berbagai cara dan berbagai media sesuai yang diakses oleh pangsa pasar potensial. Rincian jumlahmedia yang diakses tertera pada tabel 13.

Media yang paling banyak diakses oleh responden adalah media sosial, yaitu sebanyak 20,43\%. Media lain yang banyak diakses adalah website (16,51\%). Banyak juga responden yang menjawab bahwa informasi dari guru akan sangat membantu mereka dalam mengambil keputusan, yaitu sebanyak 16,10\%. Guru adalah orang yang dipercaya akan memberi informasi yang jujur, faktual dan akurat, mereka juga percaya guru memiliki banyak wawasan terkait perguruan tinggi dan jurusan yang ada. Informasi dari keluarga menempati urutan ke empat disusul dengan kunjungan promosi ke sekolah (sosialisasi di kelas/aula).

Tabel 13 Jumlah media yang diakses untuk mencari informasi

\begin{tabular}{crc}
\hline Jumlah Media & Jumlah Responden & $\%$ \\
\hline 1 & 30 & $13,45 \%$ \\
2 & 36 & $16,14 \%$ \\
3 & 46 & $20,63 \%$ \\
4 & 39 & $17,49 \%$ \\
5 & 33 & $14,80 \%$ \\
6 & 17 & $7,62 \%$ \\
7 & 13 & $5,83 \%$ \\
8 & 5 & $2,24 \%$ \\
9 & 0 & $0,00 \%$ \\
10 & 4 & $1,79 \%$ \\
Jumlah & 223 & $100 \%$ \\
\hline
\end{tabular}

Di luar dugaan, pameran edukasi ternyata tidak begitu menarik minat responden. Hal ini karena saat pameran, kondisi dirasakan kurang nyaman karena terlalu banyak stand yang harus dikunjungi sehingga tidak bisa intensif untuk memperoleh informasi. Saat pameran, siswa/i hanya mengumpulkan leaflet untuk kemudian mencari infirmasi lebih lanjut di website atau media sosial. Media berbasis jaringan internet di jaman sekarang memang banyak lebih unggul dalam pemasaran dibandingkan media lainnya karena kebanyakan penduduk indonesia sudah memiliki android. Begitu pula responden di sekolah-sekolah, ketika ditanyakan jenis handphone yang dimiliki, hampir seluruh responden mengaku memiliki HP berbasis jaringan internet. Melalui Handphone inilah biasanya responden mengakses berbagai informasi yang mereka butuhkan. Informasi jenis media yang diakses oleh responden terdapat pada tabel 14 . 
Tabel 14 Media pencarian informasi mengenai jurusan dan perguruan tinggi

\begin{tabular}{lrr}
\hline \multicolumn{1}{c}{$\begin{array}{c}\text { Pencarian } \\
\text { Informasi }\end{array}$} & \multicolumn{1}{c}{$\%$} & Urutan \\
\hline Kunjungan promosi & $10,49 \%$ & 5 \\
Pameran edukasi & $5,82 \%$ & 7 \\
Informasi dari guru & $16,10 \%$ & 3 \\
Informasi dari & $9,07 \%$ & 6 \\
teman & & \\
Informasi dari & $11,03 \%$ & 4 \\
keluarga/saudara & & \\
Spanduk & $5,28 \%$ & 8 \\
Media sosial & $20,43 \%$ & 1 \\
Website & $16,51 \%$ & 2 \\
Koran & $3,32 \%$ & 9 \\
Radio & $1,96 \%$ & 10 \\
\hline
\end{tabular}

Dalam memilih perguruan tinggi, responden memiliki beragam kriteria. Berdasarkan atribut, kriteria dibagi menjadi 14 kriteria sebagaimana tertera pada tabel 15. Kriteria yang dinilai paling penting oleh responden, dengan skala $1-10$, adalah tersedianya jurusan yang diminati oleh responden, dengan nilai 8,52. Urutan kedua adalah kualitas perguruan tinggi yang dilihat dari akreditasi, dengan nilai 8,32. Akreditas perguruan tinggi menunjukkan kredibilitas perguruan tinggi sebagai penyedia jasa pendidikan yang berkualitas.
Akreditasi dari pihak eksternal baik BAN PT maupun lembaga akreditasi lain, nasional mapun intrenasional, dapat meyakinkan responden untuk memilih sebuah perguruan tinggi. Beberapa responden melihat kualitas bukan hanya dari akreditasi, melainkan nama baik perguruan tinggi yang sering didengar oleh responden dari berbagai media.

Urutan ketiga dari kriteria yang dipertimbangkan adalah gedung dan sarana yang lengkap. Urutan ini, dengan nilai kepentingan 8,17, dapat digunakan sebagai salah satu strategi bagi perguruan tinggi dengan memperbaiki sarana prasarana dan mengunggahnya ke media sosial, sehingga menjadi daya tarik bagi calon mahasiswa. Urutan keempat diduduki oleh kriteria kemudahan dalam mengakses beasiswa dan urutan kelima adalah biaya yang terjangkau. Kondisi ini memang dapat diterima mengingat mayoritas penghasilan orang tua responden adalah sampai $\mathrm{Rp}$ 5.000.000,per bulan sehingga biaya untuk kuliah akan mengambil proporsi yang cukup besar dalam pengeluaran keluarga. Sebagaimana telah disebutkan sebelumnya, kerjasama perguruan tinggi dengan pemerintah maupun pihak swasta dalam hal pengadaan beasiswa akan meningkatkan minat calon mahasiswa untuk kuliah di perguruan tinggi.

Tabel 15 Penilaian kriteria untuk memilih perguruan tinggi

\begin{tabular}{lrr}
\hline \multicolumn{1}{c}{ Kriteria } & Penilaian Kriteria & Urutan kepentingan \\
\hline Ketenaran/terkenal & 4,94 & 13 \\
Lokasi dekat rumah & 4,47 & 14 \\
Lokasi strategis & 6,09 & 10 \\
Waktu kuliah yang singkat dan fleksibel & 6,10 & 9 \\
Gedung dan sarana yang lengkap & 8,17 & 3 \\
Kemudahan lulus & 7,74 & 6 \\
Kemudahan beasiswa & 8,04 & 4 \\
Kualitas perguruan tinggi (akreditasi) & 8,32 & 2 \\
Biaya terjangkau & 7,97 & 5 \\
Tersedia jurusan yang saya pilih & 8,52 & 1 \\
Keluarga/kenalan memberi rekomendasi & 6,37 & 8 \\
Banyaknya mahasiswa/teman yang & 5,46 & 11 \\
kuliah di kampus tersebut & & \\
Iklim pergaulan kampus nyaman & 7,24 & 7 \\
Banyak alumni yang sukses & 5,34 & 12 \\
\hline
\end{tabular}


Perguruan tinggi yang banyak dipilih oleh responden tertera pada tabel 16. Mayoritas responden $(23,77 \%)$ memilih Universitas Indonesia. Hal ini karena fakultas kedokteran yang paling terkenal adalah Universitas Indonesia, sementara banyak responden yang ingin mengambil jurusan kedokteran. Pilihan kedua adalah IPB, sebanyak 16,59\%. Walaupun responden hanya sedikit sekali yang nenilih pertanian, namun banyak yang memilih sains murni seperti biologi, fisika dan matematika yang memang ada di IPB serta manajemen dan komunikasi. Masih kontradiktif karena memang banyak responden mengisi jurusan yang tidak sesuai dengan program studi yang ada di IPB namun tetap memilih IPB. Namun jika dilihat dari pertanyaan keyakinan program studi yang dipilih, memang responden masih bersifat ragu dan tidak yakin akan jurusan yang dipilih sehingga sangat memungkinkan untuk memilih IPB walaupun belum tentu sesuai dengan jurusan yang mereka inginkan. Posisi berikutnya secara berturut-turut adalah UGM, ITB, UNPAD, UIN dan UNJ. Sementara untuk perguruan tinggi swasta terbanyak memilih Universitas Pakuan (4,04\%) dan Universitas Djuanda (2,67\%).

Tabel 16 Responden perguruan tinggi

\begin{tabular}{lcc}
\hline $\begin{array}{c}\text { Perguruan } \\
\text { Tinggi }\end{array}$ & $\begin{array}{c}\text { Jumlah } \\
\text { Responden }\end{array}$ & $\%$ \\
\hline UI & 53 & $23,77 \%$ \\
IPB & 37 & $16,59 \%$ \\
UGM & 28 & $12,56 \%$ \\
ITB & 22 & $9,87 \%$ \\
UNPAD & 17 & $7,62 \%$ \\
UIN & 13 & $5,83 \%$ \\
UNPAK & 9 & $4,04 \%$ \\
UPI & 9 & $4,04 \%$ \\
UNJ & 6 & $2,69 \%$ \\
UNIDA & 6 & $2,69 \%$ \\
STAN & 6 & $2,69 \%$ \\
lain-lain & 17 & $7,62 \%$ \\
Jumlah & 223 & $100, \%$ \\
\hline
\end{tabular}

\section{KESIMPULAN DAN IMPLIKASI}

Penghasilan orang tua responden mayoritas berpenghasilan sama dengan atau di bawah Rp 5.000.000. Asal jurusan di sekolah mayoritas dari IPA. Setelah lulus SMA/sederajat, sejumlah $72,92 \%$ responden berminat untuk melanjutkan pendidikan ke perguruan tinggi. Hampir seluruh responden menilai bahwa melanjutkan pendidikan ke perguruan tinggi adalah hal yang penting. Ini menjadi indikasi peluang pasar yang cukup baik bagi perguruan tinggi.

Pengambilan keputusan dalam memilih perguruan tinggi didominasi oleh diri sendiri (59,19\%). Orang tua menjadi pengambil keputusan bagi 29,15\% responden. Perguruan tinggi yang dipilih responden didominasi oleh perguruan tinggi negeri, yaitu 84,39\%. Perguruan tinggi swasta hanya dipilih oleh 15,61\% responden. Fakultas/program studi yang dipilih oleh mayoritas responden adalah kedokteran (16,89\%), pendidikan $(13,2 \%)$, syariah/ilmu agama (9,9\%) dan teknik $(8,94 \%)$. Walaupun banyak yang memilih kedokteran, namun secara keseluruhan responden lebih banyak yang memilih jurusan berbasis sosial (IPS), yaitu sejumlah $60 \%$. Responden mayoritas mengaku masih ragu dalam memilih jurusan saat kuliah nanti $(39,50 \%)$. Sementara 36,74\% sudah merasa yakin akan keputusannya, dan 23,76\% tidak memiliki keyakinan pasti akan jurusan yang akan dipilih saat kuliah. Dari 10 media promosi, rata-rata responden mengakses 3 sampai 4 media. Media yang paling banyak diakses oleh responden adalah media sosial, yaitu sebanyak $20,43 \%$. Media lain yang banyak diakses adalah website $(16,51 \%)$. Banyak juga responden yang menjawab bahwa informasi dari guru akan sangat membantu mereka dalam mengambil keputusan, yaitu sebanyak $16,10 \%$.

Kondisi ini dapat dipergunakan oleh perguruan tinggi terutama yang jurusannya 
berbasis IPS dengan mempromosikan jurusannya terutama melalui media sosial dan website, yang diikuti oleh pendekatan ke orang tua, misalkan dengan menciptakan citra yang dapat mengena di hati orang tua. Pendekatan terhadap guru dapat dilakukan dengan melakukan pertemuan langsung kepada para guru untuk memberi informasi mengenai perguruan tinggi, atau dengan mensponsori pertemuan-pertemuan guru di Kabupaten Bogor.

Dalam memilih perguruan tinggi, tiga kriteria tertinggi adalah tersedianya jurusan yang diminati oleh responden, lalu kualitas perguruan tinggi dan gedung dan sarana yang lengkap. Perguruam tinggi dapat membuat startegi pemasaran terkait informasi jurusan yang ada, peningkatan kualitas, serta perbaikan sarana dan prasarana sehingga dapat semakin diminati oleh siswa/siswi SMA/sederajat.

Perguruan tinggi yang banyak dipilih oleh responden $(23,77 \%)$ adalah Universitas Indonesia. Pilihan kedua adalah IPB, sebanyak 16,59\%. Posisi berikutnya adalah UGM (12,56\%). Sementara untuk perguruan tinggi swasta terbanyak memilih Universitas Pakuan (4,04\%) dan Universitas Djuanda $(2,67 \%)$.

\section{DAFTAR PUSTAKA}

Engel. 2001. Consumer Behavior. Harcourt CollegePublisher, Orlando, Florida.
Kotler, Philip dan Kevin Lane Keller. 2009. Manajemen Pemasaran. PT Indeks. Jakarta.

Kemeristekdikti. 2015. Statistik Pendidikan Tinggi 2014/2015. Kementerian Riset, Teknologi, dan Pendidikan Tinggi Republik Indonesia, Jakarta.

Kemeristekdikti. 2016. Laporan Tahunan 2016. Kementerian Riset, Teknologi, dan Pendidikan Tinggi Republik Indonesia, Jakarta.

BPS. 2017. Potret Pendidikan Indonesia, Statistik Pendidikan 2017. Biro Pusat Statistik, Jakarta.

Kanwil Kementerian Agama Jawa Barat. 2014. Data Siswa Madrasah Aliyah Negeri Dan Swasta Di Jawa Barat Tahun Pelajaran 2013/2014. Diakses Januari 2018.

https://Jabar2.Kemenag.Go.Id/Artikel/4 2042/Data-Siswa-Madrasah-AliyahNegeri-Dan-Swasta-Di-Jawa-BaratTahun-Pelajaran-2013-2014

Ujang Sumarwan et al. 2013. Riset Pemasaran dan Konsumen, Panduan Riset dan Kajian : Kepuasan, Perilaku Pembelian, Gaya Hidup, Loyalitas dan Persepsi Risiko. IPB Press. Bogor

Kementerian Pendidikan dan Kebudayaan. 2017. Data Pokok Pendidikan Dasar dan Menengah Direktorat Jenderal Pendidikan Dasar dan Menengah Kementerian Pendidikan dan Kebudayaan. Diakses Januari 2018. http://dapo.dikdasmen.kemdikbud.go.id /pd/2/020500 